\title{
Evaluation of the eastern equatorial Pacific SST seasonal cycle in CMIP5 models
}

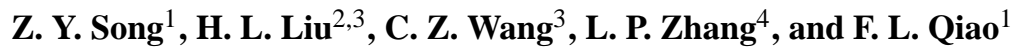 \\ ${ }^{1}$ First Institute of Oceanography, State Oceanic Administration, Qingdao, China \\ ${ }^{2}$ Cooperative Institute for Marine and Atmospheric Studies, University of Miami, Miami, FL, USA \\ ${ }^{3}$ Atlantic Oceanographic and Meteorological Laboratory, NOAA, Miami, FL, USA \\ ${ }^{4}$ Atmospheric and Oceanic Science, Princeton University, Princeton, NJ, USA \\ Correspondence to: F. L. Qiao (qiaofl@fio.org.cn)
}

Received: 19 February 2014 - Published in Ocean Sci. Discuss.: 10 April 2014

Revised: 29 August 2014 - Accepted: 17 September 2014 - Published: 23 October 2014

\begin{abstract}
The annual cycle of sea surface temperature (SST) in the eastern equatorial Pacific (EEP) has the largest amplitude in the tropical oceans, but it is poorly represented in the coupled general circulation models (CGCMs) of the Coupled Model Intercomparison Project Phase 3 (CMIP3). In this study, 18 models from CMIP5 are evaluated in terms of their capability of simulating the SST annual cycle in the EEP. Fourteen models are able to simulate the annual cycle fairly well, which suggests that the performances of CGCMs have been improved. The results of multi-model ensemble (MME) mean show that CMIP5 CGCMs can capture the annual cycle signal in the EEP with a correlation coefficient up to 0.9. Moreover, the CMIP5 models can simulate the westward propagation character of the EEP SST - in particular, EEP region 1 (EP1) near the eastern coast leading EEP region 2 (EP2) near the central equatorial Pacific by 1 to 2 months in spring. However, the models fail to reproduce the in-phase SST relationship between EP1 and EP2 in August and September. For amplitude simulations, the model SST in EP1 shows weaker seasonal variation than the observations due to the large warm SST biases from the southeastern tropical Pacific in the boreal autumn. In EP2, the simulated SST amplitudes are nearly the same as the observations while there is the presence of a quasi-constant cold bias associated with poor cold tongue simulation in the CGCMs. To improve CGCM simulation of a realistic SST seasonal cycle, local and remote SST biases that exist in both CMIP3 and CMIP5 CGCMs must be resolved at least for simulating the SSTs in the central equatorial Pacific and the southeastern tropical Pacific.
\end{abstract}

\section{Introduction}

The eastern equatorial Pacific (EEP) is a key region for El Niño-Southern Oscillation (ENSO) that affects weather, extreme events and climate globally. Although the equatorial region is dominated by the semi-annual cycle of solar radiation, the sea surface temperature (SST) seasonal variation in the EEP exhibits a strong annual cycle with the March-April warm phase and August-October cold phase (Mitchell and Wallace, 1992; Nigam and Chao, 1996), which is different from the semi-annual cycle in the western equatorial Pacific due to the sun crossing the Equator twice a year. Substantial attention has been devoted to understand the mechanisms of the SST annual cycle (Mitchell and Wallace, 1992; Giese and Carton, 1994; Xie, 1994, 2004; Mechoso et al., 1995; Nigam and Chao, 1996; Dewitt and Edwin, 1999). Numerous physical processes have been hypothesized to contribute to the annual cycle in the EEP (reviewed by Xie, 2004), such as wind-evaporation-SST feedback, stratus-SST feedback and upwelling-SST feedback. Because the annual cycle in the EEP involves complex dynamical and physical interaction among climate subsystems, it can serve as an indicator for the performance of the coupled general circulation models (CGCMs).

Since the pioneering work of developing a climate model by Manabe and Bryan (1969), CGCMs have achieved significant progress and can provide credible basic climate simulation, particularly through several important climate model intercomparison programs such as the Coupled Model Intercomparison Project (CMIP), the Paleoclimate Modelling Intercomparison Project (PMIP) and the Cloud Feedback 

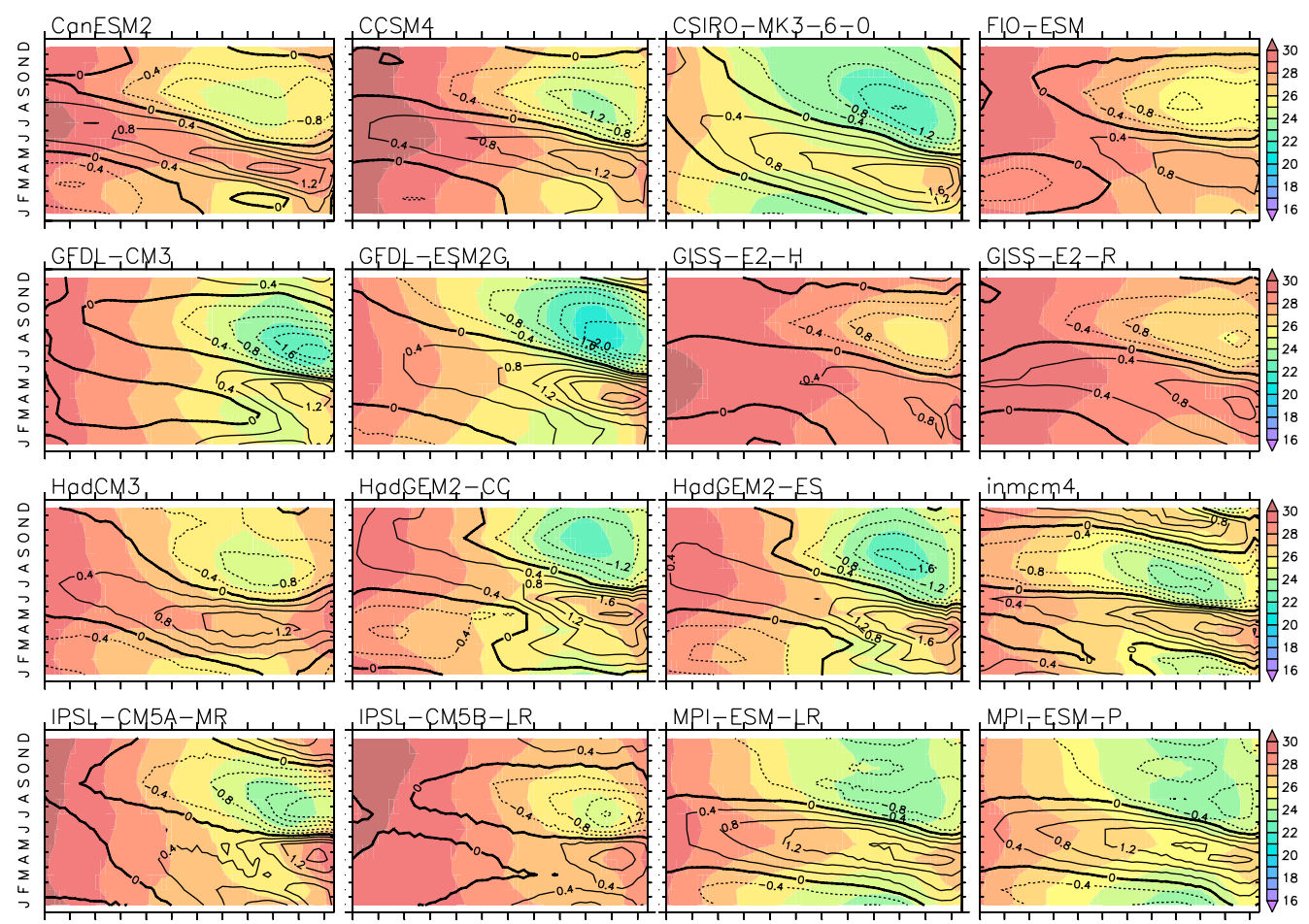

$M P I-E S M-L R$
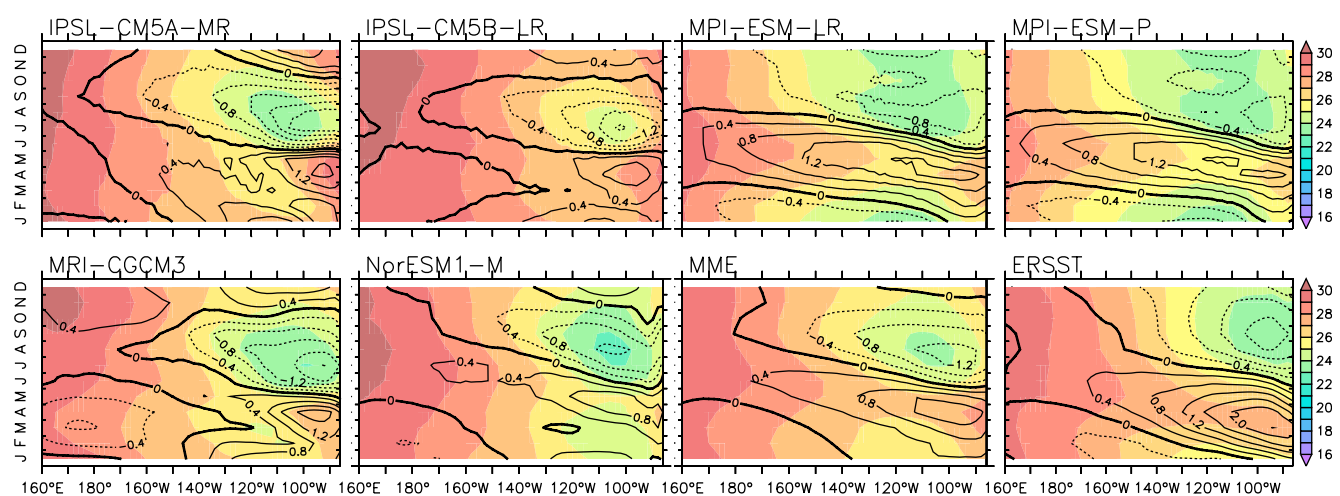

Figure 1. Seasonal cycle of sea surface temperature (SST) in the eastern equatorial Pacific (EEP). Shadings represent climatological SST, and contours represent SST anomalies relative to climatological annual mean.

Model Intercomparison Project (CFMIP). Climate models are important because climate process research and climate projection depend on them. Despite the progress, model biases still persist in the state-of-the-art CGCMs in terms of simulating the SST seasonal cycle in the EEP (Mechoso et al., 1995; Covey et al., 2000; Latif et al., 2001; Xie et al., 2007). Several years ago, De Szoeke and Xie (2008) compared the SST results of 14 global CGCMs in the CMIP Phase 3 (CMIP3), and showed that eight of these models simulated two cold phases in the EEP rather than a single cold phase as observed. For example, the simulation of the Community Climate System Model version 3 (CCSM3), which was one of the CMIP3 models, has a robust SST semi-annual cycle in the EEP. This problem was regarded as one of the six challenges for the further development of CCSMs (Collins et al., 2006). Several studies have reported that the EEP SST annual cycle has been improved in their climate models (Gent et al., 2011; Yu et al., 2013). The model outputs of the CMIP Phase 5 (CMIP5) were released recently, which include the latest version of models participating in CMIP3 and some new models. Therefore, a natural question is how well the
SST annual cycle in the EEP is reproduced in CMIP5 models.

This study aims to use the outputs of the CMIP5 historical simulations to evaluate the EEP SST annual cycle simulation in the newest versions of coupled models. A brief description of the models and validation data sets used in this study are presented in Sect. 2. Section 3 presents the simulations of CMIP5 models, and Sect. 4 provides the conclusion and discussion.

\section{Models and data sets}

In this study, the historical model simulations used are summarized in Table 1. This new generation of CMIP5 CGCMs was from 12 scientific organizations across 10 countries, and the simulations have been submitted to the Program for Climate Model Diagnosis and Intercomparison (PCMDI) for the Intergovernmental Panel on Climate Change Fifth Assessment Report (Taylor et al., 2012). Each historical simulation was integrated from pre-industry spin-up experiment and was 
Table 1. List of the CMIP5 models whose output are analyzed in this study.

\begin{tabular}{|c|c|c|c|}
\hline No. & Model & Model center & Reference \\
\hline 1 & CanESM2 & Canadian Centre for Climate Modelling and Analysis (Canada) & Chylek et al. (2011) \\
\hline 2 & CCSM4 & National Center for Atmospheric Research (United States) & Gent et al. (2011) \\
\hline 3 & CSIRO-Mk3-6-0 & $\begin{array}{l}\text { Australian Commonwealth Scientific and Industrial Research Organi- } \\
\text { zation Marine and Atmospheric Research, and Queensland Climate } \\
\text { Change Centre of Excellence (Australia) }\end{array}$ & Rotstayn et al. (2010) \\
\hline 4 & FIO-ESM & First Institute of Oceanography (China) & Qiao et al. (2013) \\
\hline $\begin{array}{l}5 \\
6\end{array}$ & $\begin{array}{l}\text { GFDL-CM3 } \\
\text { GFDL-ESM2G }\end{array}$ & Geophysical Fluid Dynamics Laboratory (United States) & $\begin{array}{l}\text { Griffies et al. (2011) } \\
\text { Dunne et al. (2012) }\end{array}$ \\
\hline $\begin{array}{l}7 \\
8\end{array}$ & $\begin{array}{l}\text { GISS-E2-H } \\
\text { GISS-E2-R }\end{array}$ & Goddard Institute for Space Studies (United States) & Shindell et al. (2013) \\
\hline $\begin{array}{r}9 \\
10 \\
11\end{array}$ & $\begin{array}{l}\text { HadCM3 } \\
\text { HadGEM2-CC } \\
\text { HadGEM2-ES }\end{array}$ & Met Office Hadley Centre (United Kingdom) & $\begin{array}{l}\text { Smith et al. (2010) } \\
\text { Collins et al. (2011) } \\
\text { Jones et al. (2011) }\end{array}$ \\
\hline 12 & inmem4 & Institute for Numerical Mathematics (Russia) & Volodin et al. (2010) \\
\hline $\begin{array}{l}13 \\
14\end{array}$ & $\begin{array}{l}\text { IPSL-CM5A-MR } \\
\text { IPSL-CM5B-LR }\end{array}$ & Institute Pierre Simon Laplace (France) & $\begin{array}{l}\text { Hourdin et al. (2013a) } \\
\text { Hourdin et al. (2013b) }\end{array}$ \\
\hline $\begin{array}{l}15 \\
16\end{array}$ & $\begin{array}{l}\text { MPI-ESM-LR } \\
\text { MPI-ESM-P }\end{array}$ & Max Planck Institute for Meteorology (Germany) & Giorgetta et al. (2013) \\
\hline 17 & MRI-CGCM3 & Meteorological Research Institute (Japan) & Yukimoto et al. (2012) \\
\hline 18 & NorESM1-M & Norwegian Climate Centre (Norway) & Bentsen et al. (2013) \\
\hline
\end{tabular}

then forced by solar, volcanic, aerosol, and greenhouse gas forcing for the period of 1850-2005. In this study, we select the monthly outputs from 1949 to 2005 for analysis.

Simulation results were compared with the SST data set of the observations, which is the monthly data from the National Oceanic and Atmospheric Administration extended reconstructed SST version 3b (ERSST v3b) (Smith et al., 2008). This data set is a global monthly gridded data set generated by using in situ data from the International Comprehensive Ocean-Atmosphere Data set (ICOADS) with missing data filled in by statistical methods. To validate model simulations, we also used the ERSST monthly data from 1949 to 2005.

\section{Results}

\subsection{Comparison}

The annual cycle is one of the major features of SST variability in the EEP (Mitchell and Wallace, 1992; Nigam and Chao, 1996; Xie, 1994, 2004). As shown in Fig. 1, the observed EEP SST reaches the peak at $27^{\circ} \mathrm{C}$ during March and April and exhibits a minimum of $23^{\circ} \mathrm{C}$ during September and October. This annual cycle, approximately $4{ }^{\circ} \mathrm{C}$ in amplitude, is mainly restricted in the region between 110 and $85^{\circ} \mathrm{W}$ along the Equator. So, we define the region from 110 to $85^{\circ} \mathrm{W}$ and $5^{\circ} \mathrm{S}$ to $5^{\circ} \mathrm{N}$ as the EP region 1 (EP1). The annual cycle is almost non-existent to the west of $140^{\circ} \mathrm{W}$. Then, we define the transition region $\left(140-110^{\circ} \mathrm{W}\right.$ and $5^{\circ} \mathrm{S}-$ $5^{\circ} \mathrm{N}$ ) as EP2, where SST shows a much weaker annual cycle compared with that in EP1. The warming in EP1 tends to propagate westward and takes 1-month lead over EP2 in the warm phase (see ERSST in Fig. 1). After June, the variations in EP1 and EP2 are in phase, which suggests that the mechanisms behind the warm and cold phases in the EEP vary with season. Therefore, the two regions of EP1 and EP2 are selected for analysis in this study.

The major characteristics of the SST annual cycle in the EEP are effectively represented in the 14 models classified as Group 1, which includes CanESM2, CCSM4, CSIRO-MK36-0, FIO-ESM, GFDL-ESM2G, GISS-E2-H, GISS-E2R, HadCM3, HadGEM2-CC, HadGEM2-ES, IPSL-CM5AMR, IPSL-CM5B-LR, MPI-ESM-LR, and MPI-ESM-P. These model results suggest that the CGCMs in CMIP5 show improvement in capturing the annual cycle of the EEP SST from the previous generation CGCMs of the CMIP3 (which were not effective in simulating the annual SST cycle in the EEP). However, four models classified as Group 2, which includes GFDL-CM3, INMCM4, MRI-CGCM3, and NorESM1-M, produce semi-annual cycle; namely, they are 

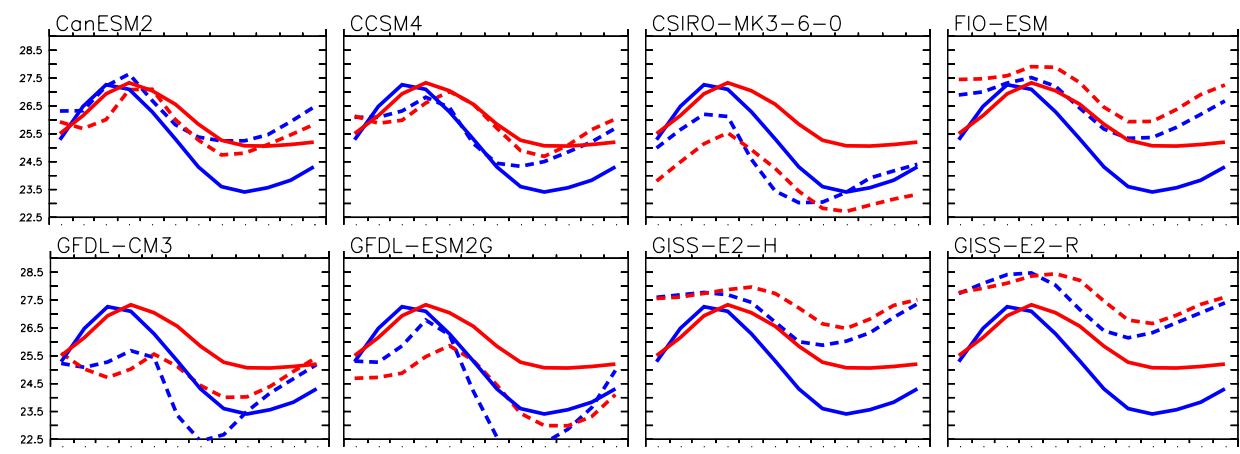

GFDL-ESM $2 G$
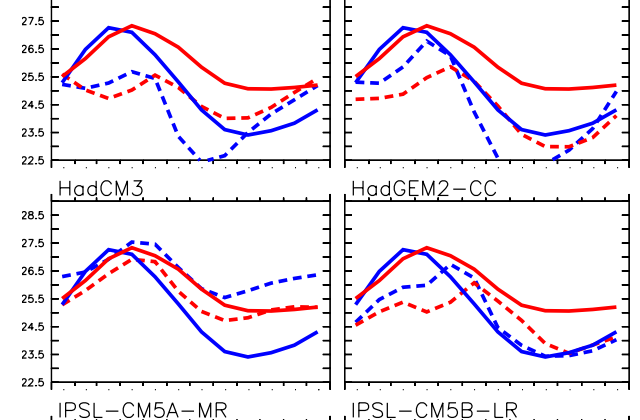

GISS-E2-H
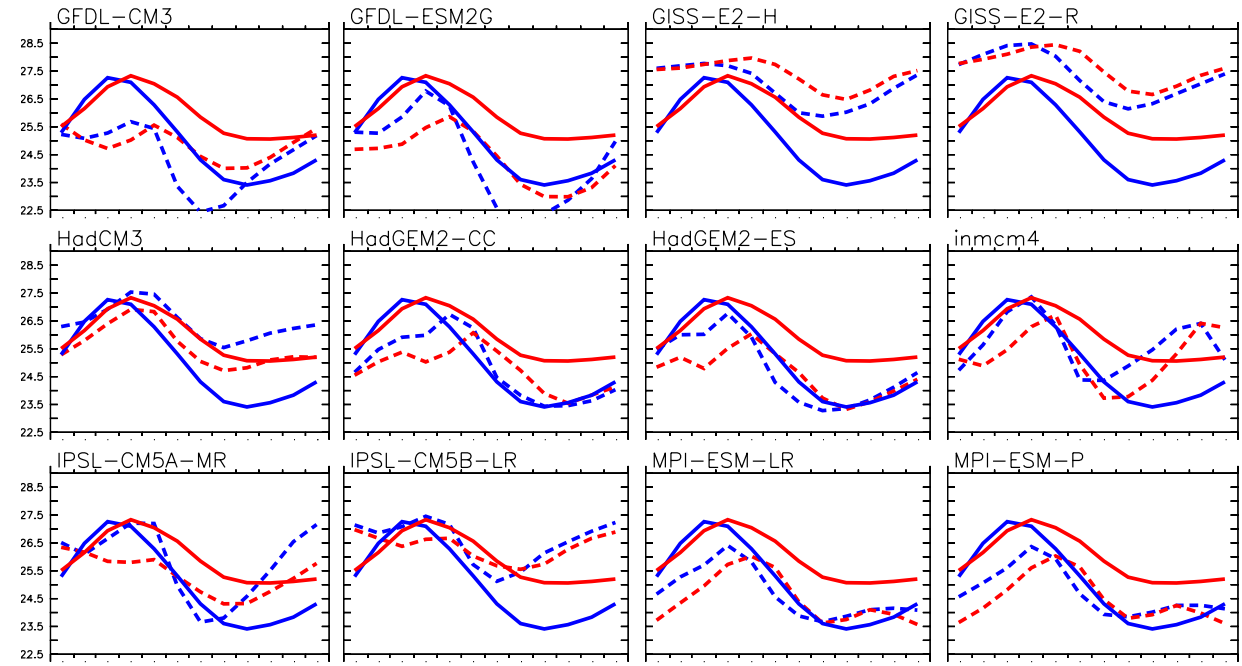

IPSL-CM5B-LR
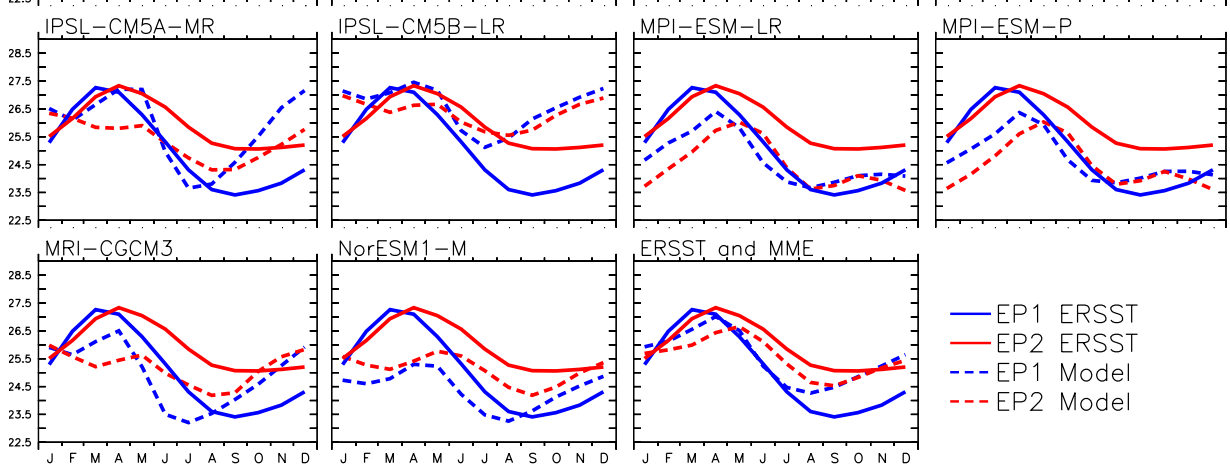

ERSST and MME
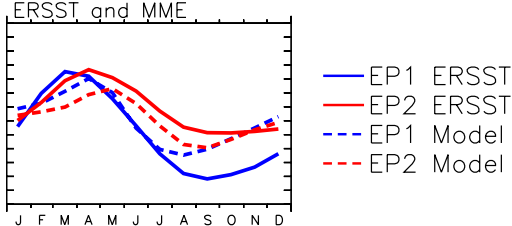

Figure 2. SST seasonal cycles for EEP region $1\left(\mathrm{EP} 1 ; 110-85^{\circ} \mathrm{W}, 5^{\circ} \mathrm{S}-5^{\circ} \mathrm{N}\right.$; blue line) and EEP region $2\left(\mathrm{EP} 2 ; 140-110^{\circ} \mathrm{W}, 5^{\circ} \mathrm{S}-5^{\circ} \mathrm{N}\right.$; red line). The solid curves are the ERSST, and the dashed are model outputs.

still not able to simulate the realistic annual cycle of the EEP SST. Among the models in Group 1, CanESM2, FIOESM, GISS-E2-H, GISS-E2-R, HadCM3, and IPSL-CM5BLR have weaker seasonal variation in the EP1 region in comparison with the observations. In addition, the annual cycle of the EEP SST in CSIRO-MK3-6-0 extends to $180^{\circ} \mathrm{W}$, and the westward propagation processes in its EP1 to EP2 are seen in both warm and cold seasons (Fig. 1 CSIRO-MK3-6-0). This implies the westward Rossby-wave propagation mechanism (Xie, 2004) in the warm phase of observations is overexaggerated in CSIRO-MK3-6-0.

The regional average SSTs, shown in Fig. 2, are used to show the seasonal cycle in the EEP. The EP2 SST is observed to follow the EP1 SST variation in March and April; in the following seasons, EP2 SST varies in phase as EP1 when the Pacific cold tongue develops, but with a weaker amplitude (Fig. 2, ERSST). The CMIP5 CGCMs used in the present study are not able to accurately represent this feature. In March and April, 16 out of the 18 models, CanESM2, CCSM4, CSIRO-MK3-6-0, FIO-ESM, GFDL_CM3, GFDLESM2G, GISS-E2-H, GISS-E2-R, HadCM3, HadGEM2CC, HadGEM2-ES, INMCM4, IPSL-CM5A-MR, IPSLCM5B-LR, MPI-ESM-LR, and MPI-ESM-P, show that EP1 leads EP2 by 1 to 2 months. However in August and September, only two models, FIO-ESM and HadCM3, demonstrate that the SSTs in EP1 and EP2 are in phase. A comparison between the multi-model ensemble (MME) mean and observation reveals that CMIP5 CGCMs can capture the annual cycle signal in both the EP1 and EP2 regions and westward propagation process in spring. In addition, the correlation coefficient between MME and observations can reach 0.9. However, the CMIP5 models fail to reproduce the in-phase SST relationship in EP1 and EP2 in August and September when the cold tongue develops.

It is notable that the SST amplitude of $\operatorname{MME}\left(2.7^{\circ} \mathrm{C}\right)$ in $\mathrm{EP} 1$ is weaker than that observed $\left(3.8^{\circ} \mathrm{C}\right)$, whereas that in $\mathrm{EP} 2\left(2.1^{\circ} \mathrm{C}\right)$ is nearly the same as that observed $\left(2.4^{\circ} \mathrm{C}\right)$. For the MME in EP1, the weaker amplitude is due to the cold bias in the boreal spring at its high peak and the warm bias is up to $1.0^{\circ} \mathrm{C}$ in the boreal autumn at its low peak. However, for the MME in EP2, a quasi-constant cold bias is present throughout the year; therefore, its SST amplitude is the same as that observed. To determine the reason behind the difference in amplitudes of MME in EP1 and EP2, we trace the sources of the model deficiencies in the following subsection. 


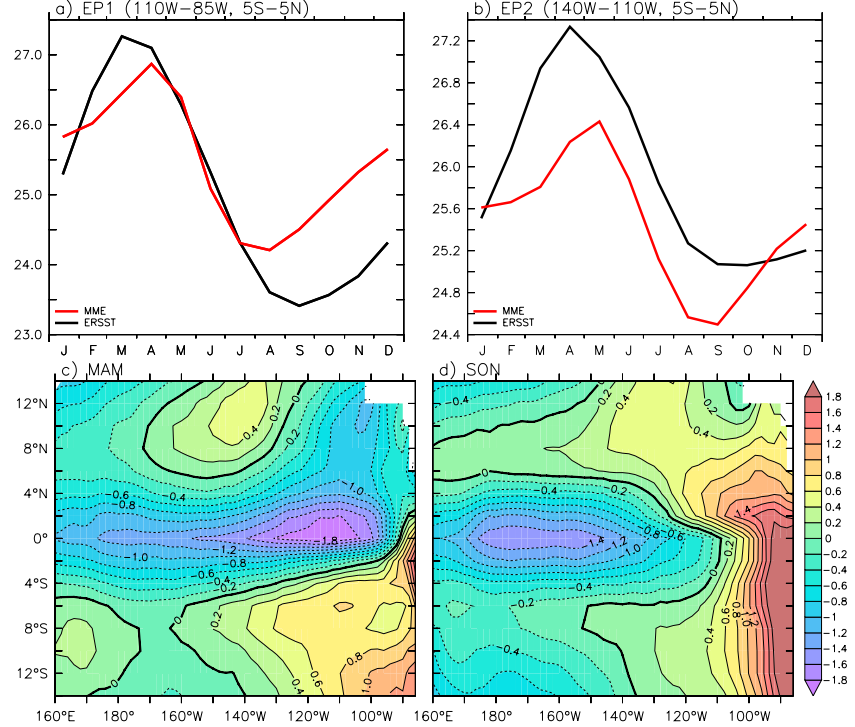

Figure 3. Multi-model ensemble (MME) mean SST for the eastern equatorial Pacific seasonal cycle (a and b) and tropical eastern Pacific SST biases in spring (c) and autumn (d).

\subsection{Analysis}

Figure 3a shows that in the region of EP1 the SST seasonal cycle of the CGCMs is similar with the observations in terms of phase. However, the MME exhibits cold SST bias during the boreal spring (Fig. 3c) and warm bias (Fig. 3d) during the cooling phase after July. The SST bias in the models reduces the amplitude of EP1 annual cycle. The SeptemberNovember warm bias in EP1 expands from the southeastern tropical Pacific, where the warm bias exists throughout the year. The model annual cycle in EP2 (Fig. 3b) shows a cold bias within $1{ }^{\circ} \mathrm{C}$ from January through October. This cold equatorial SST bias is associated with the excessive cold tongue bias, which is a classic tropical bias in CGCMs that still exists in CMIP5 models (Li and Xie, 2014; Wang et al., 2014).

The zonal mean SST bias patterns in EP1 (Fig. 4a) and EP2 (Fig. 4b) show that both regions have cold SST biases in February-May. The cold bias in EP2 extends to the boreal winter. In EP1, however, the warm SST bias develops in August and expands from the southeastern Pacific associated with a southward wind bias (Fig. 4a). In the boreal summer, the southeasterly trade wind prevails in the EP1 region. Therefore, the southward wind bias reduces the southeast trade wind over EP1 and leads to weaker latent heat loss from the ocean, leading to a warm SST bias. It should be pointed that the southward wind bias is associated with the double ITCZ (Intertropical Convergence Zone) bias, which weakens the meridional wind through the wind-evaporation-SST feedback (De Szoeke and Xie, 2008). Furthermore, an eastward wind bias develops in EP1 in August, and this westerly wind bias enhances the EP1 warm bias through the Bjerknes
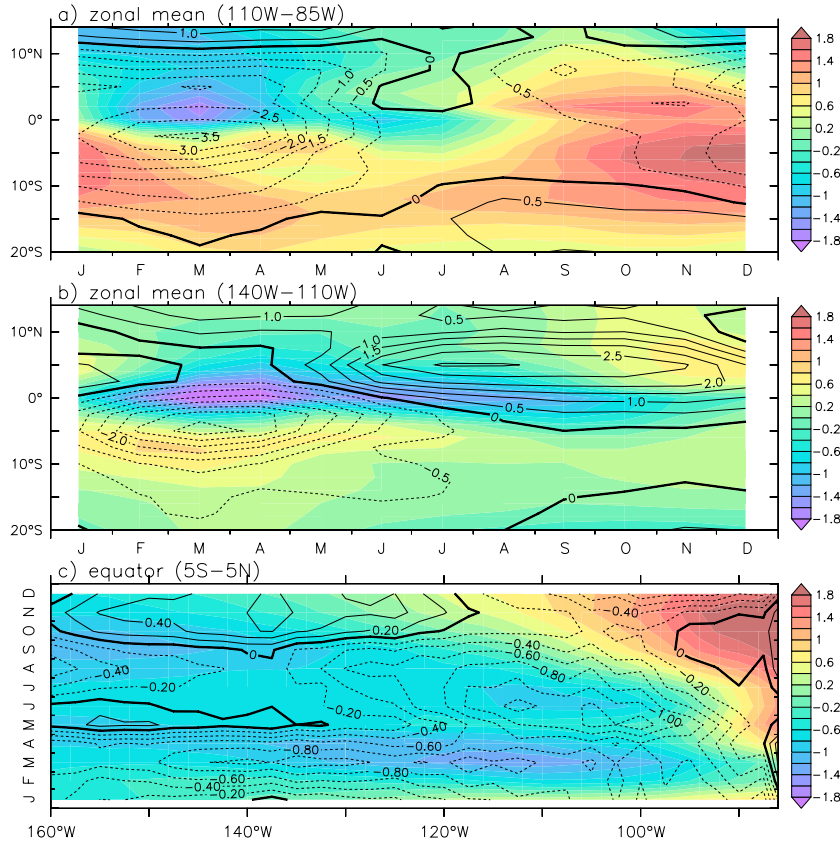

Figure 4. Evaluations of MME SST biases (shadings), surface northward wind biases (contours in $\mathbf{a}$ and $\mathbf{b}$ ), and eastward wind biases (contours in $\mathbf{c}$ ).

feedback. Eventually, the cold bias in the boreal spring and the warm bias in the boreal summer in EP1 cause the weaker annual cycle simulation in the models, in contrast to the observations. It was suggested that the cold bias in the boreal spring originated in the ocean ( $\mathrm{Li}$ and $\mathrm{Xie}, 2012)$. Therefore, understanding the causes of the warm bias of EP1 in the cold phase will contribute to improvements in the next-generation CGCMs in terms of EEP annual cycle simulations. Moreover, the warm SST bias in the EP1 region in the boreal summer may explain why most CMIP5 models fail to reproduce the in-phase SST relationship between the EP1 and EP2 regions in August and September when the cold tongue develops.

\section{Conclusions and discussion}

We conducted a comprehensive evaluation of the performance of CMIP5 CGCMs in terms of simulating the annual cycle in the EEP. Fourteen out of the 18 models are able to capture the main characteristics of the SST annual cycle in the EEP. In addition, a comparison between the MME with the observations revealed that the CMIP5 CGCMs can capture the annual cycle signal in both the EP1 and EP2 regions with a correlation coefficient up to 0.9. The CMIP5 models can simulate the SST westward propagation character in the EEP, with SST in EP1 leading that in EP2 by 1 to 2 months in spring. However, they fail to reproduce the in-phase SST 
relationship between EP1 and EP2 regions in August and September when the cold tongue develops.

For the MME SST simulation in EP1, both the cold bias along the Equator in the warm phase and the warm bias in the cold phase lead to a weaker annual SST cycle in CGCMs when compared with the observations. In EP2, however, the amplitude is nearly identical to the observed, because a quasi-constant cold bias persisted throughout the year. Known as an excessive cold tongue, this problem is common and still exists in the CMIP5 models ( $\mathrm{Li}$ and Xie, 2014). To improve the capability of the CGCMs in simulating a realistic SST seasonal cycle in the EEP, both the local and remote climatological SST biases (Wang et al., 2014) that exist in both CMIP3 and CMIP5 CGCMs, such as the climatological simulation of the cold tongue region and the southeastern tropical Pacific, must be resolved.

Acknowledgements. This research was supported by National Natural Science Foundation of China (NSFC) grant 41476023, the National Basic Research Program of China (973 Program) grant 2010CB950500 and NSFC-Shandong Joint Fund for Marine Science Research Centres grant U1406404. We acknowledge the ESG-PCMDI for providing the CMIP5 model datasets. We are also very grateful to two anonymous reviewers for their careful review and valuable comments, which led to substantial improvement of this manuscript.

Edited by: D. Stevens

\section{References}

Bentsen, M., Bethke, I., Debernard, J. B., Iversen, T., Kirkevåg, A., Seland, Ø., Drange, H., Roelandt, C., Seierstad, I. A., Hoose, C., and Kristjánsson, J. E.: The Norwegian Earth System Model, NorESM1-M - Part 1: Description and basic evaluation of the physical climate, Geosci. Model Dev., 6, 687-720, doi:10.5194/gmd-6-687-2013, 2013.

Chylek, P., Li, J., Dubey, M. K., Wang, M., and Lesins, G.: Observed and model simulated 20th century Arctic temperature variability: Canadian Earth System Model CanESM2, Atmos. Chem. Phys. Discuss., 11, 22893-22907, doi:10.5194/acpd-1122893-2011, 2011.

Collins, W. D., Bitz, C. M., Blackmon, M. L., Bonan, G. B., Bretherton, C. S., Carton, J. A., Chang, P., Doney, S. C., Hack, J. J., Henderson, T. B., Kiehl, J. T., Large, W. G., McKenna, D. S., Santer, B. D., and Smith, R. D.: The Community Climate System Model Version 3 (CCSM3), J. Climate, 19, 2122-2143, doi:10.1175/JCLI3761.1, 2006.

Collins, W. J., Bellouin, N., Doutriaux-Boucher, M., Gedney, N., Halloran, P., Hinton, T., Hughes, J., Jones, C. D., Joshi, M., Liddicoat, S., Martin, G., O’Connor, F., Rae, J., Senior, C., Sitch, S., Totterdell, I., Wiltshire, A., and Woodward, S.: Development and evaluation of an Earth-System model - HadGEM2, Geosci. Model Dev., 4, 1051-1075, doi:10.5194/gmd-4-10512011, 2011.

Covey, C., Abe-Ouchi, A., Boer, G. J., Boville, B. A., Cubasch, U., Fairhead, L., Flato, G. M., Gordon, H., Guilyardi, E., Jiang, X.,
Johns, T. C., Le Treut, H., Madec, G., Meehl, G. A., Miller, R., Noda, A., Power, S. B., Roeckner, E., Russell, G., Schneider, E. K., Stouffer, R. J., Terray, L., and von Storch, J.-S.: The seasonal cycle in coupled ocean-atmosphere general circulation models, Clim. Dynam., 16, 775-787, doi:10.1007/s003820000081, 2000.

De Szoeke, S. P. and Xie, S.-P.: The tropical eastern Pacific seasonal cycle: Assessment of errors and mechanisms in IPCC AR4 coupled ocean-atmosphere general circulation models, J. Climate, 21, 2573-2590, doi:10.1175/2007JCLI1975.1, 2008.

Dewitt, D. G. and Edwin, K. S.: The processes determining the Annual Cycle of Equatorial Sea Surface Temperature: A coupled General Circulation Model Perspective, Mon. Weather Rev., 127, 381-395, doi:10.1175/15200493(1999)127<0381:TPDTAC>2.0.CO;2, 1999.

Dunne, J. P., John, J. G., Adcroft, A. J., Griffies, S. M., Hallberg, R. W., Shevliakova, E., Stouffer, R. J., Cooke, W., Dunne, K. A., Harrison, M. J., Krasting, J. P., Malyshev, S. L., Milly, P. C. D., Phillipps, P. J., Sentman, L. T., Samuels, B. L., Spelman, M. J., Winton, M., Wittenberg, A. T., and Zadeh, N.: GFDL's ESM2 Global Coupled Climate-Carbon Earth System Models. Part I: Physical Formulation and Baseline Simulation Characteristics, J. Climate, 25, 6646-6665, doi:10.1175/JCLI-D-11-00560.1, 2012.

Gent, P. R., Danabasoglu, G., Donner, L. J., Holland, M. M., Hunke, E. C., Jayne, S. R., Lawrence, D. M., Neale, R. B., Rasch, P. J., Vertenstein, M., Worley, P. H., Yang, Z.-L., and Zhang, M.: The Community Climate System Model version 4, J. Climate, 24, 4973-4991, doi:10.1175/2011JCLI4083.1, 2011.

Giese, B. S. and Carton, J. A.: The seasonal cycle in a coupled ocean-atmosphere model, J. Climate, 7, 1208-1217, doi:10.1175/1520-0442(1994)007<1208:TSCICO>2.0.CO;2, 1994.

Giorgetta, M. A., Jungclaus, J., Reick, C. H., Legutke, S., Bader, J., Böttinger, M., Brovkin, V., Crueger, T., Esch, M., Fieg, K., Glushak, K., Gayler, V., Haak, H., Hollweg, H.-D., Ilyina, T., Kinne, S., Kornblueh, L., Matei, D., Mauritsen, T., Mikolajewicz, U., Mueller, W., Notz, D., Pithan, F., Raddatz, T., Rast, S., Redler, R., Roeckner, E., Schmidt, H., Schnur, R., Segschneider, J., Six, K. D., Stockhause, M., Timmreck, C., Wegner, J., Widmann, H., Wieners, K.-H., Claussen, M., Marotzke, J., and Stevens, B.: Climate and carbon cycle changes from 1850 to 2100 in MPI-ESM simulations for the coupled model intercomparison project phase 5, J. Adv. Model. Earth Syst., 5, 572-597, doi:10.1002/jame.20038, 2013.

Griffies, S. M., Winton, M., Donner, L. J., Horowitz, L. W., Downes, S. M., Farneti, R., Gnanadesikan, A., Hurlin, W. J., Lee, H.C., Liang, Z., Palter, J. B., Samuels, B. L., Wittenberg, A. T., Wyman, B. L., Yin, J., and Zadeh, N.: The GFDL CM3 Coupled Climate Model: Characteristics of the Ocean and Sea Ice Simulations, J. Climate, 24, 3520-3544, doi:10.1175/2011JCLI3964.1, 2011.

Hourdin, F., Foujols, M.-A., Codron, F., Guemas, V., Dufresne, J.L., Bony, S., Denvil, S., Guez, L., Lott, F., Ghattas, J., Braconnot, P., Marti, O., Meurdesoif, Y., and Bopp, L.: Impact of the LMDZ atmospheric grid configuration on the climate and sensitivity of the IPSL-CM5A coupled model, Clim. Dynam., 40, 2167-2192, doi:10.1007/s00382-012-1411-3, 2013a.

Hourdin, F., Grandpeix, J.-Y., Rio, C., Bony, S., Jam, A., Cheruy, F., Rochetin, N., Fairhead, L., Idelkadi, A., Musat, I., Dufresne, J.L., Lahellec, A., Lefebvre, M.-P., and Roehrig, R.: LMDZ5B: the 
atmospheric component of the IPSL climate model with revisited parameterizations for clouds and convection, Clim. Dynam., 40, 2193-2222, doi:10.1007/s00382-012-1343-y, 2013b.

Jones, C. D., Hughes, J. K., Bellouin, N., Hardiman, S. C., Jones, G. S., Knight, J., Liddicoat, S., O’Connor, F. M., Andres, R. J., Bell, C., Boo, K.-O., Bozzo, A., Butchart, N., Cadule, P., Corbin, K. D., Doutriaux-Boucher, M., Friedlingstein, P., Gornall, J., Gray, L., Halloran, P. R., Hurtt, G., Ingram, W. J., Lamarque, J.-F., Law, R. M., Meinshausen, M., Osprey, S., Palin, E. J., Parsons Chini, L., Raddatz, T., Sanderson, M. G., Sellar, A. A., Schurer, A., Valdes, P., Wood, N., Woodward, S., Yoshioka, M., and Zerroukat, M.: The HadGEM2-ES implementation of CMIP5 centennial simulations, Geosci. Model Dev., 4, 543-570, doi:10.5194/gmd-4-543-2011, 2011.

Latif, M., Sperber, K., Arblaster, J., Braconnot, P., Chen, D., Colman, A., Cubasch, U., Cooper, C., Delecluse, P., Dewitt, D., Fairhead, L., Flato, G., Hogan, T., Ji, M., Kimoto, M., Kitoh, A., Knutson, T., Le Treut, H., Li, T., Manabe, S., Marti, O., Mechoso, C., Meehl, G., Power, S., Roeckner, E., Sirven, J., Terray, L., Vintzileos, A., Voß, R., Wang, B., Washington, W., Yoshikawa, I., Yu, J., and Zebiak, S.: ENSIP: the El Nino simulation intercomparison project, Clim. Dynam., 18, 255-276, doi:10.1007/s003820100174, 2001.

Li, G. and Xie, S.-P.: Origins of tropical-wide SST biases in CMIP multi-model ensembles, Geophys. Res. Lett., 39, L22703, doi:10.1029/2012GL053777, 2012.

Li, G. and Xie, S.-P.: Tropical Biases in CMIP5 Multimodel Ensemble: The Excessive Equatorial Pacific cold tongue and Double ITCZ Problems, J. Climate, 27, 1765-1780, doi:10.1175/JCLID-13-00337.1, 2014

Manabe, S. and Bryan, K.: Climate calculation with a combined ocean-atmosphere model, J. Atmos. Sci., 26, 768-789, doi:10.1175/1520-0469(1969)026<0786:CCWACO>2.0.CO:2, 1969.

Mechoso, C. R., Robertson, A. W., Barth, N., Davey, M. K., Delecluse, P., Gent, P. R., Ineson, S., Kirtman, B., Latif, M., Le Treut, H., Nagai, T., Neelin, J. D., Philander, S. G. H., Polcher, J., Schopf, P. S., Stockdale, T., Suarez, M. J., Terray, L., Thual, O., and Tribbia, J. J.: The seasonal cycle over the tropical Pacific in coupled ocean-atmosphere general circulation models, J. Climate, 123, 2825-2838, doi:10.1175/15200493(1995)123<2825:TSCOTT>2.0.CO:2, 1995.

Mitchell, T. P. and Wallace, J. M.: The annual cycle in equatorial convection and sea surface temperature, J. Climate, 5, 1140-1156, doi:10.1175/15200042(1992)005<1140:TACIEC>2.0.CO:2, 1992.

Nigam, S. and Chao, Y.: Evolution dynamics of tropical oceanatmosphere annual cycle variability, J. Climate, 9, 3187-3205, doi:10.1175/1520-0442(1996)009<3187:EDOTOA>2.0.CO:2, 1996.

Qiao, F., Song, Z., Bao, Y., Shu, Q., Huang, C., and Zhao, W.: Description and evaluation of an earth system model climate with surface gravity wave, J. Geophys. Res.-Ocean., 118, 4514-4524, doi:10.1002/jgrc.20327, 2013.
Rotstayn, L., Collier, M., Dix, M., Feng, Y., Gordon, H., O’Farrell, S., Smith, I., and Syktus, J.: Improved simulation of Australian climate and ENSO-related climate variability in a GCM with an interactive aerosol treatment, Int. J. Climatology, 30, 1067-1088, doi:10.1002/joc.1952, 2010.

Shindell, D. T., Pechony, O., Voulgarakis, A., Faluvegi, G., Nazarenko, L., Lamarque, J.-F., Bowman, K., Milly, G., Kovari, B., Ruedy, R., and Schmidt, G. A.: Interactive ozone and methane chemistry in GISS-E2 historical and future climate simulations, Atmos. Chem. Phys., 13, 2653-2689, doi:10.5194/acp-13-26532013, 2013.

Smith, D. M., Eade, R., Dunstone, N. J., Fereday, D., Murphy, J. M., Pohlman, H., and Scaife, A. A.: Skilful multi-year predictions of Atlantic hurricane frequency, Nat. Geosci., 3, 846-849, doi:10.1038/ngeo1004, 2010.

Smith, T. M., Reynolds, R. W., Peterson, T. C., and Lawrimore, J.: Improvements to NOAA's historical merged land-ocean surface temperature analysis (1880-2006), J. Climate, 21, 2283-2296, doi:10.1175/2007JCLI2100.1, 2008.

Taylor, K. E., Stoufefer, R. J., and Meehl, G. A.: An overview of CMIP5 and the experimental design, Bull. Am. Meteorol. Soc., 93, 485-498, doi:10.1175/BAMS-D-11-00094.1, 2012.

Volodin, E. M., Diansky, N. A., and Gusev, A. V.: Simulating present-day climate with the INMCM4.0 coupled model of the atmospheric and oceanic general circulations, Izvestiya, Atmos. Ocean. Phys., 46, 414-431, doi:10.1134/S000143381004002X, 2010.

Wang, C., L. Zhang, S.-K. Lee., L. Wu, and C. R. Mechoso: A global perspective on CMIP5 climate model biases, Nat. Clim. Change, 4, 201-205, 2014.

Xie, S. P.: On the genesis of the equatorial annual cycle, J. Climate, 7, 2008-2013, doi:10.1175/15200442(1994)007<2008:OTGOTE>2.0.CO:2, 1994.

Xie, S. P.: The shape of continents, air-sea interaction, and the rising branch of the Hadley circulation, in: The Hadley Circulation: Past, Present and Future, Vol. 21, Advances in Global Change Research, edited by: Diaz, H. F. and Bradley, R. S., 121-152, Springer Netherlands, 2004.

Xie, S. P., Miyama, T., Wang, Y., Xu, H., de Szoeke, S. P., Small, R. J. O., Richards, K. J., Mochizuki, T., and Awaji, T.: A regional ocean-atmosphere model for eastern Pacific climate: toward reducing tropical biases, J. Climate, 20, 1504-1522, doi:10.1175/JCLI4080.1, 2007.

Yu, Y. Q., He, J., Zheng, W. P., and Luan, Y. H.: Annual cycle and interannual variability in the Tropical Pacific as Simulated by Three Versions of FGOALS, Adv. Atmos. Sci., 30, 621-637, doi:10.1007/s00376-013-2184-2, 2013.

Yukimoto, S., Adachi, Y., Hosaka, M., Sakami, T., Yoshimura, H., Hirabara, M., Tanaka, T. Y., Shindo, E., Tsujino, H., Deushi, M., Mizuta, R., Yabu, S., Obata, A., Nakano, H., Koshiro, T., Ose, T., and Kiton, A.: A new global climate model of the Meteorological Research Institute: MRI-CGCM3 - Model description and basic performance, J. Meteorol. Soc. Jpn. II, 90A, 23-64, doi:10.2151/jmsj.2012-A02, 2012. 